\title{
A Study of Biochemical Parameters in Hypothyroid Cases and Euthyroid Controls.
}

\author{
Dr. Ch. Venkata Ramana M.D., \\ Associate Professor Of Biochemistry Guntur Medical College, Guntur, A.P. India.
}

\begin{abstract}
Thyroid disorders are the most common endocrine disorders. In the present study 51 hypothyroid cases and 50 Euthyroid controls were analysed for Thyroid Profile, Lipid Profile, Body Mass Index (BMI) waist circumference, Hip circumference and waist hip ratio. Out of 51 Hypothyroid subjects studied, 5 are having subclinical Hypothyroidism, 20 are having mild Hypothyroidism, 14 Subjects are having moderate Hypothyroidism and 12 are having severe Hypothyroidism. It was found that Hypothroidism is associated with Obesity and hence weight reduction and regular physical exercise are to be advised for Hypothyroid Patients. It was also observed that Hypercholesterolemia with increased $L D L-C$ and decreased $H D L-C$ were noticed in Hypothyroid subjects and hence early detection of Hypothyroidism will help in prevention of progression of the disease to severity.
\end{abstract}

Key Words: BMI-Body Mass Index; HDL-C High Density Lipoprotein Cholesterol ; LDL-C Low Density Lipoprotein Cholesterol.

\section{Introduction}

Thyroid diseases are among the commonest endocrine disorders worldwide. Worldwide about 42 million people have thyroid dysfunction on various categories. In India, thyroid disorders are most common among all endocrine disorders and hypothyroidism being more common than hyperthyroid state and carcinoma thyroid ${ }^{1}$. The incidence of overt hypothyroidism is about 4.1 cases per 1000 women / year and 0.6 cases per $1000 \mathrm{men}$. The prevalence has been reported to be $1-2 \%$ in women and $0.1 \%$ in men.

Long back, thyroid function was assessed only by clinical examination, Basal metabolic rate (BMR) calculation and total cholesterol estimation. It was the time, when patients with high serum cholesterol concentration were regarded as evidence for 'Pre myxedema' in the absence of symptoms of hypothyroidism, rather than measurement of serum $\mathrm{T}_{4}$ and Thyroid Stimulating Hormone (TSH). Mild and subclinical hypothyroidism which were identified only as a biochemical entity gained its importance only in 1990's. Hormone measurement has now assumed a position of pivotal role in practice of scientific medicine. Hypothyroidism and Obesity frequently co-exit. Hypothyroidism leads to increased body weight by increasing much deposits and by salt and water retention. Extreme obesity also leads to increased $\mathrm{TSH}^{2}$. Hyperlipidaemia particularly hypercholesterolemia, is a well documented, significant health consequence associated with hypothyroidism and obesity. Dyslipidemia associated with hypothyroidism is characterized by a decrease in HDL-Cholesterol and an increase in both total cholesterol and low Density Lipoprotein - Cholesterol (LDL-C). In the light of the above facts present study is undertaken to evaluate association of Obesity, dyslipidaemia in Hypothyroid subjects as early detection and treatment will help to prevent progression of disease to severity.

\section{Materials And Methods}

In the present study 51 Hypothyroid cases, within the age group of 21 to 54 years, admitted in Govt. General Hospital, Guntur from 01-03-2013 to 30-04-2014 and 50 Euthyroid controls of same age group were studied.

\section{Inclusion Criteria}

\section{Criteria Of The Study Subjects}

1. Hypothyroid patients of age group 21-54 years.

Exclusion Criteria

1. Patients with Diabetes Melltius / hypertension / other metabolic disorders.

2. Pregnant women

3. Post thyroidectomy patient

4. Patients on any other treatment.

In both cases and controls Thyroid Profile, Lipid Profile and BMI, waist circumference, hip circumference and waist hip ratio were estimated. 
Estimation of Serum THYROID STIMULATING HORMONE (TSH) : Enzyme Linked Immunosorbent Assay (ELISA) kit obtained from Ranbaxy Laboratories was used.

Principle : In a quantitative Enzyme Immuno Assay (EIA), high affinity antibodies react with antigen to form an insoluble sandwich complex on the surface of a coated micro plate. The antigen from the specimen gets linked at the surface of the well through interaction of reactive IgG coated on the well and affinity purified xantigen IgG conjugated with Horse Radish Peroxidase (HRP). The fraction of the $\mathrm{x}$-antigen IgG conjugated with enzyme that does not bind to the coated well is washed away. The enzyme activity, which is proportional to antigen concentration in the sample, is measured by addition of substrate. By utilizing calibrators of known antigen values, a does response curve can be generate from which the antigen concentration in a sample can be found out.

Estimation Of Serum Free Thyroxine (fT $)_{4}$ : (EIA) Kit obtained from Ranbaxy Laboratories was used.

\section{Principle : (Competitive EIA)}

In a competitive EIA, enzyme linked antigen competes with antigen from the specimen for a limited number of binding sties on the immobilized antibody coated on the micro wells. Unbound antigen fraction is then washed away. The enzyme activity in the antibody bound function which is inversely proportional to the native antigen concentration is measured by addition of the substrate. By utilizing calibrators of known antigen values, a does response curve may be generated from which the antigen concentration of an unknown can be obtained.

Estimation Of Serum Ft 3 : (EIA) Kit obtained from Ranbaxy Laboratories was used.

\section{Principle : (Competitive EIA)}

In a competitive EIA, enzyme linked antigen competes with antigen form the serum for a limited number of binding sites on the immobilized antibody coated on the micro wells. Unbound antigen fraction is then washed away. The enzyme activity in the antibody bound fraction which is inversely proportional to the native antigen concentration is measured by addition of the substrate. By utilizing calibrators of known antigen values, a dose response curve may be generated from which the antigen concentration of an unknown can be obtained.

Lipid Profile : Total serum cholesterol was estimated by ZLATKIS, ZAK and BOYLE method. HDL-C was assessed by phosphotungstate - Magnesium chloride precipitation method. (ref. BURSTEIN, M. SCHOLNICK, H.R. AND MORFIN 1970). Serum triglycerides were estimated by Acetyl acetone method. VLDL-C was calculated by using Friedewalds formula.

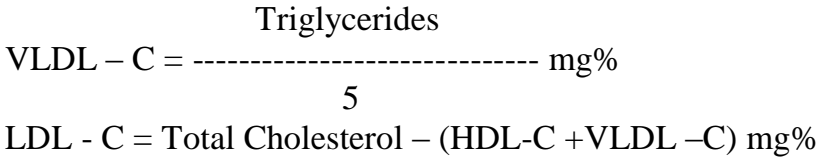

BMI (BODY MASS INDEX) and WAIST HIP RATIO were calculated by the following formulas:

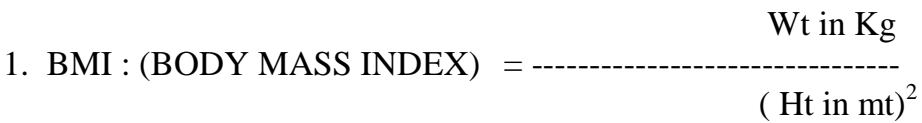

Waist circumference in $\mathrm{cms}$

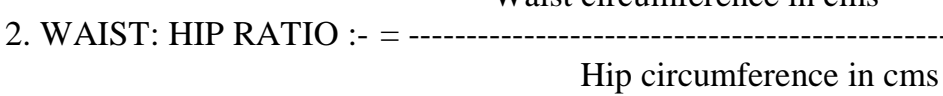


A Study of Biochemical Parameters in Hypothyroid Cases and Euthyroid Controls.

\section{Figures And Tables}

Table - 1 : Distribution Of Subjects According To Their Gender

\begin{tabular}{|l|l|l|}
\hline \multirow{2}{*}{ Groups } & Gender \\
\cline { 2 - 3 } & Males n(\%) & Females n (\%) \\
\hline Hypothyroids (Cases n =51) & $12(23.5 \%)$ & $39(76.57 \%)$ \\
\hline Euthyroids (Controls n=50) & $10(20 \%)$ & $40(80 \%)$ \\
\hline
\end{tabular}

Table - 2 : Categorization Of Cases According To Thyroid Profile

\begin{tabular}{|c|c|c|c|}
\hline Groups [TSH $\mu \mathrm{IU} / \mathrm{ml}]$ (n) & $\begin{array}{l}\text { TSH }[\mu I U / m l] \\
\text { Mean } \pm \text { SD } \\
(\text { Range) }\end{array}$ & $\begin{array}{l}\text { fT }_{4}[\mathrm{ng} / \mathrm{dl}] \\
\text { Mean } \pm \text { SD } \\
(\text { Range) }\end{array}$ & $\begin{array}{l}\mathrm{fT}_{3}[\mathrm{pg} / \mathrm{ml}] \\
\text { Mean } \pm \mathrm{SD} \\
(\text { Range })\end{array}$ \\
\hline $\begin{array}{l}\text { SUBCLINICAL } \\
\text { (5) }\end{array}$ & $\begin{array}{l}8.15 \pm 2.12 \\
(5.49 \text { to } 12.7)\end{array}$ & $\begin{array}{l}0.93 \pm 0.07 \\
(0.83 \text { to } 1.03)\end{array}$ & $\begin{array}{l}2.68 \pm 0.89 \\
(1.45 \text { to } 3.8)\end{array}$ \\
\hline $\begin{array}{l}\text { MILD I [5-10] } \\
(20)\end{array}$ & $\begin{array}{l}7.09 \pm 1.02 \\
(5.23 \text { to } 9.31)\end{array}$ & $\begin{array}{l}0.88 \pm 0.15 \\
(0.63 \text { to } 1.67)\end{array}$ & $\begin{array}{l}1.2 \pm 0.28 \\
(0.02 \text { to } 3.63)\end{array}$ \\
\hline $\begin{array}{l}\text { MODERATE II } \\
{[10-20]} \\
(14)\end{array}$ & $\begin{array}{l}15.27 \pm 2.83 \\
(10.04 \text { to } 19.89)\end{array}$ & $\begin{array}{l}0.83 \pm 0.15 \\
(0.45 \text { to } 1.053)\end{array}$ & $\begin{array}{l}1.022 \pm 0.212 \\
(0.48 \text { to } 1.35)\end{array}$ \\
\hline $\begin{array}{l}\text { SEVERE III } \\
{[>20]} \\
(12)\end{array}$ & $\begin{array}{l}43.49 \pm 14.96 \\
(24.08 \text { to } 66.9)\end{array}$ & $\begin{array}{l}0.55 \pm 0.26 \\
(0.09 \text { to } 1.35)\end{array}$ & $\begin{array}{l}1.18 \pm 0.46 \\
(0.09 \text { to } 3.62)\end{array}$ \\
\hline $\begin{array}{l}\text { CONTROLS } \\
{[0.39-5.0]} \\
(50)\end{array}$ & $\begin{array}{l}2.23 \pm 0.62 \\
(0.4 \text { to } 4.6)\end{array}$ & $\begin{array}{l}1.2 \pm 0.26 \\
(0.81 \text { to } 2.05)\end{array}$ & $\begin{array}{l}1.9 \pm 0.52 \\
(1.21 \text { to } 3.7)\end{array}$ \\
\hline
\end{tabular}

Table - 3 : Comparison Of Lipid Profile In Hypothyroid Study Groups And Euthyroids

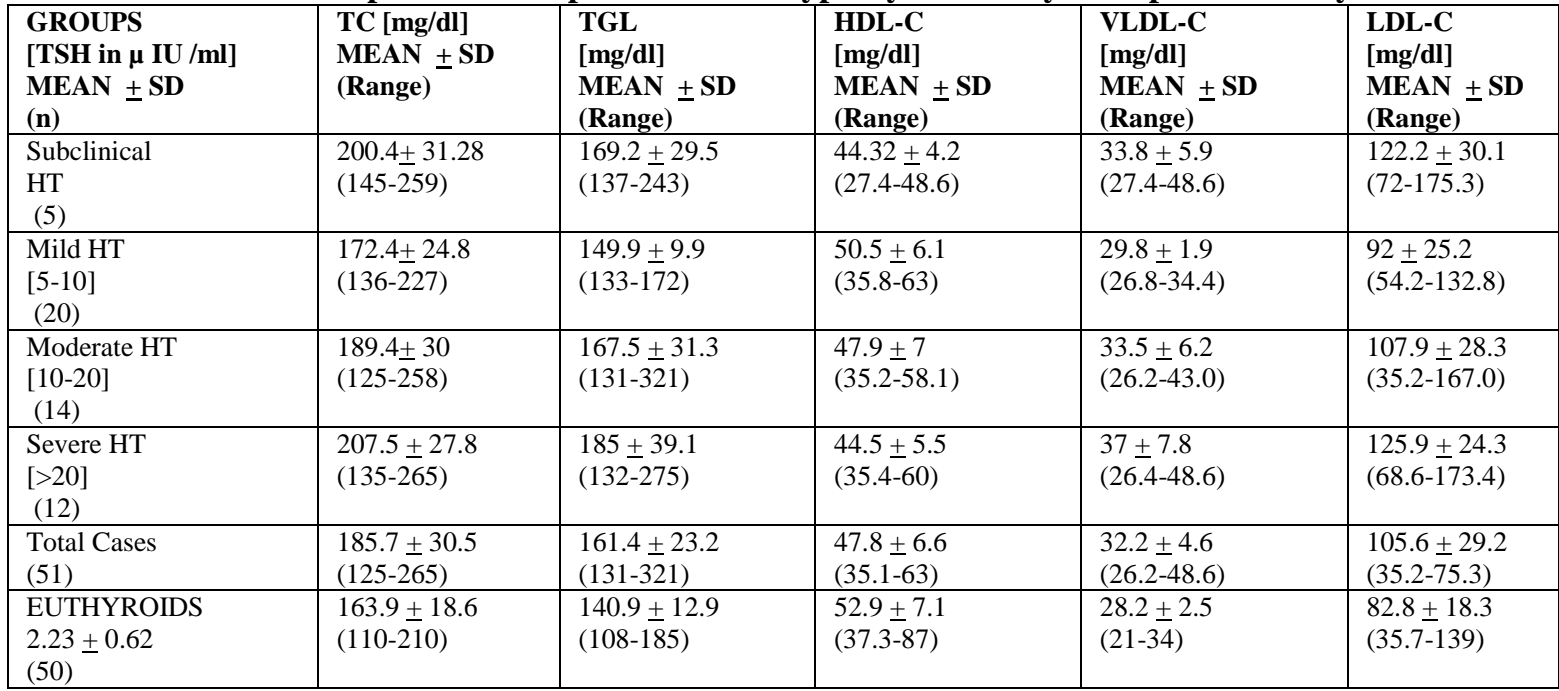

Table - 4 : Bmi In Hypothyroid Study Groups And Euthyroids

\begin{tabular}{|c|c|c|c|c|c|c|}
\hline \multirow[t]{2}{*}{ Category } & \multirow[t]{2}{*}{ No of Sample } & \multicolumn{2}{|c|}{ BMI $\left(\mathrm{kg} / \mathrm{m}^{2}\right)$} & \multirow{2}{*}{$\begin{array}{l}\text { BMI }\left(\mathrm{kg} / \mathrm{m}^{2}\right) \\
\operatorname{MEAN} \pm \mathrm{SD}\end{array}$} & \multirow{2}{*}{$\begin{array}{l}\text { BMI } \\
\text { Mean Rank Z } \\
\text { Score }\end{array}$} & \multirow[t]{2}{*}{ Significance } \\
\hline & & Min & Max & & & \\
\hline Mild & 20 & 17.90 & 39.20 & $26.01 \pm 5.06$ & 39.60 & 0.286 (NS) \\
\hline Control & 50 & 20.30 & 33.90 & $24.72 \pm 3.15$ & 33.86 & \\
\hline Moderate & 14 & 24 & 34.20 & $27.62 \pm 3.01$ & 46.93 & $0.001 * *$ \\
\hline Control & 50 & 20.30 & 33.90 & $24.72 \pm 3.15$ & 28.46 & \\
\hline Severe & 12 & 27.274 & 35.56 & $31.78 \pm 2.86$ & 53.67 & $0.000 * *$ \\
\hline Control & 50 & 20.30 & 33.90 & $24.72+3.15$ & 26.18 & \\
\hline Subclincial & 5 & 22 & 34.40 & $26.30 \pm 4.65$ & 32.60 & $0.521(\mathrm{NS})$ \\
\hline Control & 50 & 20.30 & 33.90 & $24.72 \pm 3.15$ & 27.54 & \\
\hline
\end{tabular}

NS - Not Significant ** Significant 
A Study of Biochemical Parameters in Hypothyroid Cases and Euthyroid Controls.

Table - 5 : Waist Hip Ratio In Hypothyroid Study Groups And Euthyroids

\begin{tabular}{|c|c|c|c|c|c|c|}
\hline \multirow[t]{2}{*}{ Category } & \multirow[t]{2}{*}{ No of Sample } & \multicolumn{2}{|c|}{ W: H } & \multirow{2}{*}{$\begin{array}{l}\text { W: H } \\
\text { Mean } \pm \text { SD }\end{array}$} & \multirow[t]{2}{*}{$\mathbf{Z}$ value } & \multirow[t]{2}{*}{$p$ value } \\
\hline & & Min & Max & & & \\
\hline Mild HT & 20 & 0.83 & 0.93 & $0.87 \pm 0.02$ & 47.53 & $0.003 * *$ \\
\hline Control & 50 & 0.82 & 0.90 & $0.85 \pm 0.01$ & 30.69 & \\
\hline Moderate HT & 14 & 0.85 & 0.93 & $0.89 \pm 0.03$ & 52.25 & $0.000 * *$ \\
\hline Control & 50 & 0.82 & 0.90 & $0.85 \pm 0.01$ & 26.97 & \\
\hline Severe HT & 12 & 0.86 & 1.02 & $0.94 \pm 0.04$ & 55.21 & $0.000 * *$ \\
\hline Control & 50 & 0.82 & 0.90 & $0.85 \pm 0.01$ & 25.81 & \\
\hline Subclinical HT & 5 & 0.88 & 1.00 & $0.934 \pm 0.05$ & 52.00 & $0.000 * *$ \\
\hline Control & 50 & 0.82 & 0.90 & $0.85 \pm 0.01$ & 25.60 & \\
\hline
\end{tabular}

\section{** Significant}

Table - 6 : Total Cholesterol Levels In Different Hypothyroid Groups \& Euthyroids

\begin{tabular}{|c|c|c|c|c|c|c|}
\hline \multirow[t]{2}{*}{ Category } & \multirow[t]{2}{*}{ No of Sample } & \multicolumn{2}{|c|}{ Cholesterol (mg/dl) } & \multirow{2}{*}{$\begin{array}{l}\text { Cholesterol } \\
(\mathrm{mg} / \mathrm{dl}) \\
\text { Mean + SD }\end{array}$} & \multirow[t]{2}{*}{$Z$ value } & \multirow[t]{2}{*}{ p value } \\
\hline & & Min & Max & & & \\
\hline $\begin{array}{l}\text { Mild HT } \\
\text { Euthyroids }\end{array}$ & $\begin{array}{l}20 \\
50\end{array}$ & $\begin{array}{l}136 \\
110\end{array}$ & $\begin{array}{l}227 \\
210\end{array}$ & $\begin{array}{l}172.4 \pm 28.8 \\
163.9 \pm 22.53\end{array}$ & $\begin{array}{l}38.98 \\
34.11 \\
30.69 \\
\end{array}$ & $\begin{array}{l}0.366 \\
(\mathrm{NS})\end{array}$ \\
\hline $\begin{array}{l}\text { Moderate HT } \\
\text { Euthyroids }\end{array}$ & $\begin{array}{l}14 \\
50 \\
\end{array}$ & $\begin{array}{l}125 \\
110 \\
\end{array}$ & $\begin{array}{l}258 \\
210 \\
\end{array}$ & $\begin{array}{l}187.8 \pm 37.3 \\
163.9 \pm 22.53\end{array}$ & $\begin{array}{l}42.25 \\
29.77\end{array}$ & $0.027 *$ \\
\hline $\begin{array}{l}\text { Severe HT } \\
\text { Euthyroids }\end{array}$ & $\begin{array}{l}12 \\
50 \\
\end{array}$ & $\begin{array}{l}132 \\
110 \\
\end{array}$ & $\begin{array}{l}275 \\
210 \\
\end{array}$ & $\begin{array}{l}199.2 \pm 42.57 \\
163.9 \pm 22.53 \\
\end{array}$ & $\begin{array}{l}44.63 \\
28.35 \\
\end{array}$ & $0.005 * *$ \\
\hline $\begin{array}{l}\text { Subclinical HT } \\
\text { Euthyroids }\end{array}$ & $\begin{array}{l}5 \\
50\end{array}$ & $\begin{array}{l}145 \\
110\end{array}$ & $\begin{array}{l}259 \\
210\end{array}$ & $\begin{array}{l}200.4 \pm 42.7 \\
163.9 \pm 22.53\end{array}$ & $\begin{array}{l}41.50 \\
26.65\end{array}$ & $0.046^{*}$ \\
\hline
\end{tabular}

\section{NS - Not Significant}

** Significant

Table - 7 : Triglyceride Levels In Different Hypothyroid Groups \& Euthyroids

\begin{tabular}{|c|c|c|c|c|c|c|}
\hline \multirow[t]{2}{*}{ Category } & \multirow[t]{2}{*}{ No of Sample } & \multicolumn{2}{|c|}{ TGL (mg/dl) } & \multirow{2}{*}{$\begin{array}{l}\text { TGL }(\mathrm{mg} / \mathrm{dl}) \\
\text { Mean } \pm \text { SD }\end{array}$} & \multirow[t]{2}{*}{$\mathrm{z}$ value } & \multirow[t]{2}{*}{ p value } \\
\hline & & Min & Max & & & \\
\hline Mild HT & 20 & 133 & 172 & $149.0 \pm 11.91$ & 43.00 & \\
\hline Euthyroids & 50 & 105 & 185 & $140.9 \pm 16.80$ & 32.50 & $\begin{array}{l}0.051 \\
\text { (NS) }\end{array}$ \\
\hline Moderate HT & 14 & 131 & 321 & $167.8 \pm 49.94$ & 42.14 & \\
\hline Euthyroids & 50 & 105 & 185 & $140.9+16.80$ & 29.80 & $0.028 *$ \\
\hline Severe HT & 12 & 132 & 223 & $171.9 \pm 31.76$ & 45.50 & \\
\hline Euthyroids & 50 & 105 & 185 & $140.9 \pm 16.80$ & 28.14 & $0.003 *$ \\
\hline Subclinical HT & 5 & 137 & 243 & $169.2 \pm 43.36$ & 39.30 & \\
\hline Euthyroids & 50 & 105 & 185 & $140.9 \pm 16.80$ & 26.87 & $0.099(\mathrm{NS})$ \\
\hline
\end{tabular}

NS - Not Significant

** Significant

Table - 8 : Hdl-C Levels In Different Hypothyroid Groups \& Euthyroids

\begin{tabular}{|c|c|c|c|c|c|c|}
\hline \multirow[t]{2}{*}{ Category } & \multirow[t]{2}{*}{ No of Sample } & \multicolumn{2}{|c|}{ HDL-C (mg/dl) } & \multirow{2}{*}{$\begin{array}{l}\text { HDL-C }(\mathrm{mg} / \mathrm{dl}) \\
\text { Mean } \pm \text { SD }\end{array}$} & \multirow[t]{2}{*}{$z$ value } & \multirow[t]{2}{*}{ p value } \\
\hline & & Min & Max & & & \\
\hline Mild HT & 20 & 35.80 & 63 & $50.55 \pm 7.87$ & 32.65 & \\
\hline Euthyroids & 50 & 37.30 & 87 & $52.95 \pm 9.81$ & 36.64 & 0.459 (NS) \\
\hline Moderate HT & 14 & 35.20 & 63 & $47.95 \pm 8.64$ & 26.04 & \\
\hline Euthyroids & 50 & 37.30 & 87 & $52.95 \pm 9.81$ & 4.31 & $0.142(\mathrm{NS})$ \\
\hline Severe HT & 12 & 35 & 60 & $44.58 \pm 7.17$ & 18.54 & \\
\hline Euthyroids & 50 & 7.30 & 87 & $52.95 \pm 9.81$ & 34.61 & $0.006^{* *}$ \\
\hline Subclinical HT & 5 & 35.10 & 50.40 & $44.34 \pm 5.87$ & 12.90 & \\
\hline Euthyroids & 50 & 37.30 & 87 & $52.95 \pm 9.81$ & 29.51 & $0.024 *$ \\
\hline
\end{tabular}

NS - Not Significant

** Significant 
A Study of Biochemical Parameters in Hypothyroid Cases and Euthyroid Controls.

Table - 9 : Ldl-C Levels In Different Hypothyroid Groups \& Euthyroids

\begin{tabular}{|c|c|c|c|c|c|c|}
\hline \multirow[t]{2}{*}{ Category } & \multirow[t]{2}{*}{ No of Sample } & \multicolumn{2}{|c|}{ LDL-C (mg/dl) } & \multirow{2}{*}{$\begin{array}{l}\text { LDL-C }(\mathrm{mg} / \mathrm{dl}) \\
\text { Mean } \pm \text { SD }\end{array}$} & \multirow[t]{2}{*}{$z$ value } & \multirow[t]{2}{*}{ p value } \\
\hline & & Min & Max & & & \\
\hline Mild HT & 20 & 54.20 & 150.8 & $92.09+29.32$ & 39.33 & \\
\hline Euthyroids & 50 & 35.70 & 139.4 & $82.78+23.12$ & 33.97 & $0.320(\mathrm{NS})$ \\
\hline Moderate HT & 14 & 35.20 & 167 & $106.4+35.54$ & 44.07 & \\
\hline Euthyroids & 50 & 35.70 & 139.4 & $82.78+23.12$ & 29.26 & $0.009 * *$ \\
\hline Severe HT & 12 & 65 & 196.4 & $120.2+40.53$ & 45.25 & \\
\hline Euthyroids & 50 & 35.70 & 139.4 & $82.78+23.12$ & 28.20 & $0.003 * *$ \\
\hline Subclinical HT & 5 & 72 & 175.30 & $122.2+40.08$ & 43.40 & \\
\hline Euthyroids & 50 & 35.70 & 139.4 & $82.78+23.12$ & 26.46 & $0.022 *$ \\
\hline
\end{tabular}

\section{NS - Not Significant ** Significant}

Figure - 1

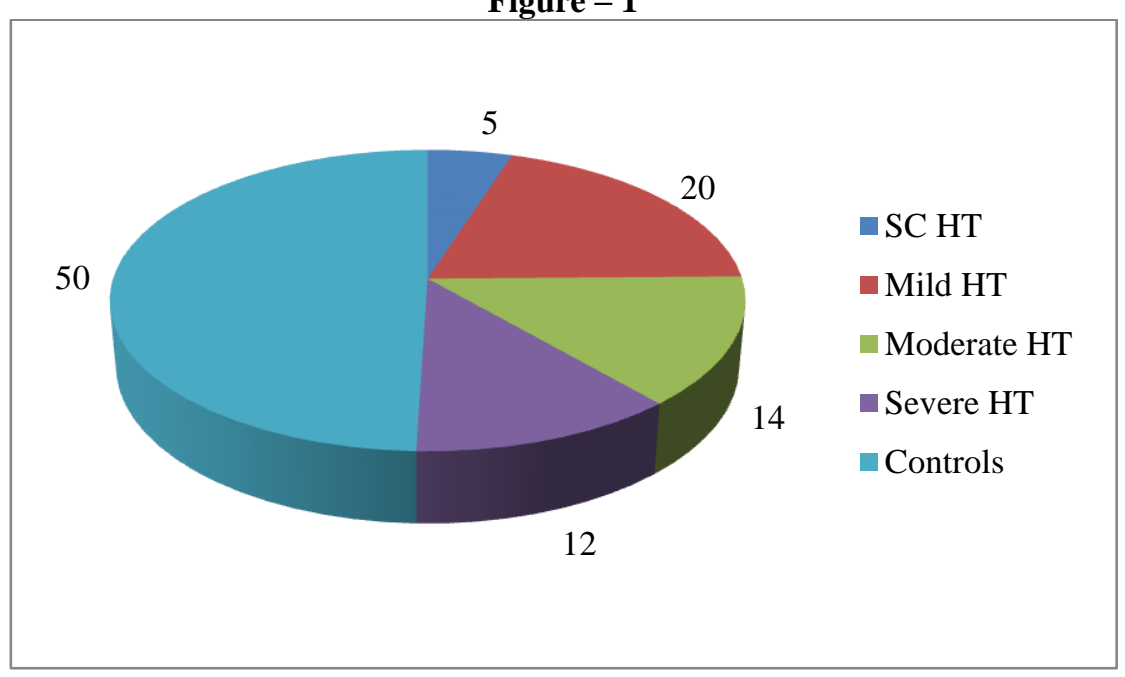

Pie diagram showing number of cases in each hypothyroid group and controls

Figure - 2

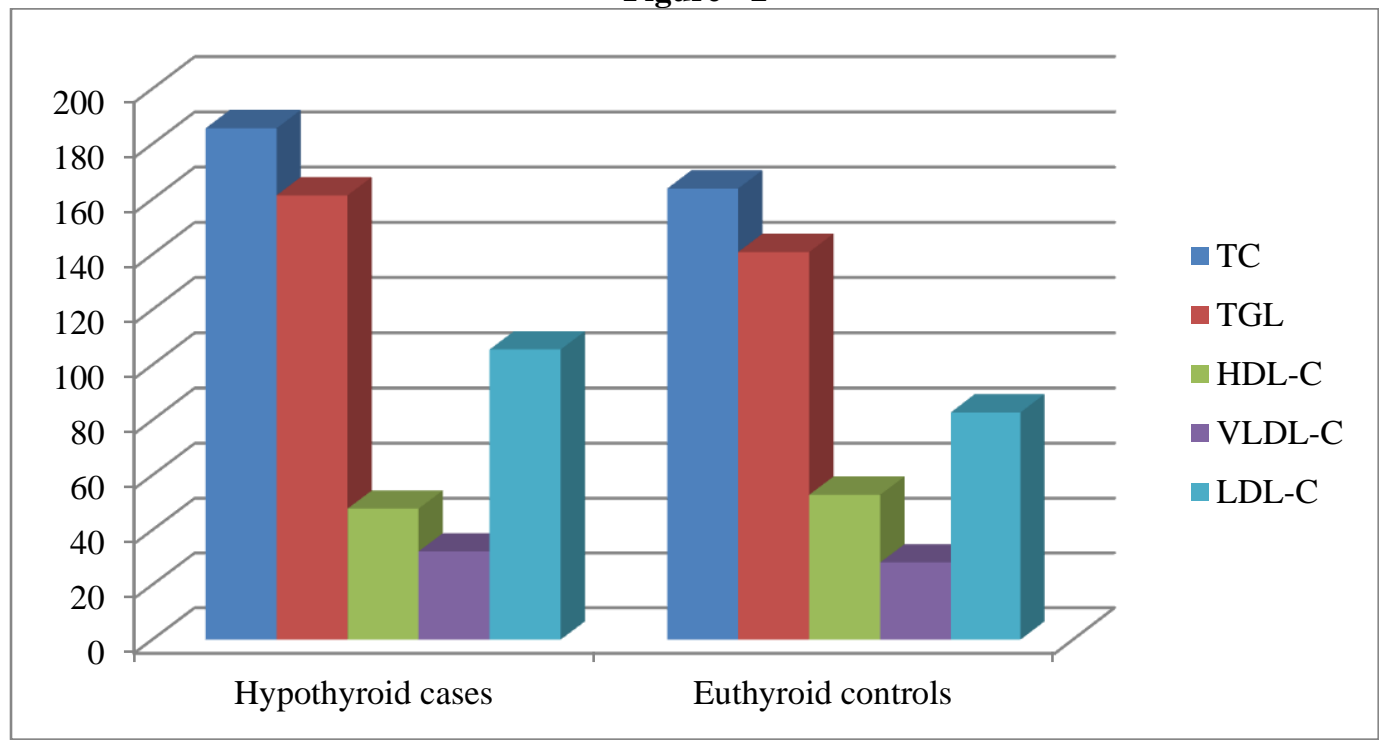

Comparison of Lipid Profile in Hypothyroid Cases Euthyroid Controls 


\section{Discussion}

In our study the proportion of Males compared to Females in both Hypothyroid cases and Euthyroid controls was very minimal. $76.5 \%$ of cases and $80 \%$ of controls are females. The study subjects were found to be in their mid- thirties with mean age of 37.1 in both cases and controls. The median age group were 36 years and 36.5 years in cases \& controls respectively. Hypothyroidism is a common condition affecting females more than males and more commonly the middle aged population ${ }^{4}$.

The hypothyroid cases were categorised into four groups ${ }^{4}$ according to their $\mathrm{TSH}, \mathrm{fT}_{4}$ and $\mathrm{fT}_{3}$ levels as subclinical (5/51), mild hypothyroids (20/51) with TSH 5-10 $\mu \mathrm{IU} / \mathrm{ml}$, moderate group (14/51) with TSH 10-20 $\mu \mathrm{IU} / \mathrm{ml}$ and severe group (12/51) with TSH $>20 \mu \mathrm{IU} / \mathrm{ml}$ and are compared against the control group with TSH $<5 \mu \mathrm{IU} / \mathrm{ml}$.

BMI: BMI is a precise tool to assess the variation in body weight. The normal BMI for Asain population is $<22.9 \mathrm{~kg} / \mathrm{m}^{2}{ }^{(\text {Ref*5) }}$. BMI in subclinical hypothyroid $\left(26.3 \mathrm{~kg} / \mathrm{m}^{2}\right)$ group was slightly elevated when compared to mild hypothyroids $\left(26.01 \mathrm{~kg} / \mathrm{m}^{2}\right)$. In the remaining groups, we found that BMI was increasing along with the TSH level, the mean BMI in each group (mild, moderate \& severe) being $26.01 \mathrm{~kg} / \mathrm{m}^{2}, 27.6$ $\mathrm{kg} / \mathrm{m}^{2}$ and $31.78 \mathrm{~kg} / \mathrm{m}^{2}$ respectively. Of these, the increase in BMI of subclinical and mild hypothyroids were not statistically significant with $\mathrm{p}$ value 0.5 and 0.3 respectively, when compared to the control group (mean $24.7 \mathrm{~kg} / \mathrm{m}^{2}$ ). BMI of Moderate \& Severe hypothyroids showed high significant increase with $\mathrm{p}$ value $<0.001$ compared to Euthyroids.

Waist Hip Ratio: Waist hip ratio values were significantly increased in subclinical, mild, moderate and severe hypothyroid subjects ( $\mathrm{p}$ value $<0.005$ ). The probable mechanism of weight gain and central obesity in hypothyroidism is thyrotropin influence on adipogenesis and on adipokinin production directly by acting on thyrotropin receptors in adipocytes and preadipocytes inducing differentiation and expansion. It also induces synthesis and release of adipokines and leptin. The weight gain that occurs in hypothyroidism is partly due to fluid retention by hydrophilic glycoprotein deposits in tissue ${ }^{3}$.

Total Cholesterol: Total cholesterol levels in subclinical, moderate and severe Hypothyroid subjects show significant increase with $\mathrm{p}$ value $<0.005$. In mild hypothyroid subject, increase in total cholesterol values are not statistically significant ( $\mathrm{p}$ value 0.4 ) compare to Euthyroids. Decreased activity of LDL-C receptors resulting in decreased receptor mediated catabolism of LDL is probably the main cause of hypercholesterolemia observed in hypothyroidism.

Triglycerides: Triglyceride levels in subclinical \& mild Hypothyroids show no significant increase (p value - subclinical 0.1, mild 0.05) when compared to Euthyroids. In moderate and severe Hypothyroids, triglyceride levels show significant increase with p value 0.020 .003 respectively. Hypertriglyceridemia in hypothyroids is explained in various studies that due to impaired clearance of both endogenous and exogenous Triglycerides from the circulation. Thyroid hormone effects the synthesis and mobilization of Triglycerides stored in adipose tissue ${ }^{3}$.

HDL - Cholesterol: HDL - Cholesterol levels in subclinical hypothyroids ( $\mathrm{p}$ value 0.024 ) and in Severe Hypothyroids ( $\mathrm{p}$ value 0.006 ) were significantly decreased compared to Euthoroids. IN mild and moderate hypothyroids, they are nto significantly decreased with $p$ values 0.459 and 0.142 respectively.

LDL Cholesterol: Increase in LDC-C levels in Subclinical Hypothyroidism ( $p$ value 0.02), Moderate HT ( $\mathrm{p}$ value 0.009) and Severe Hypothyroidism ( $\mathrm{p}$ value 0.003) ae statistically significant compared to euthyroids. In Mild Hypothyroidism increase in LDL-C levels is not statistically significant ( $\mathrm{p}$ value 0.3 ) against euthyroids. Hypercholesterolemic subjects have higher concentrations of LDL and on older LDL there is decreased cellular receptors leading to consequently reduced removal of LDL from plasma. In Hypothyroidism a higher cholesterol to protein ratio together with an increased age of LDL could contribute to the enhanced oxidizability of these particles. High serum cholesterol levels seem to represent a very strong pro-oxidant factor that can also favour LDL oxidative modification in patients with a very low metabolic rate, such as in hypothyroidism. Another possible pathophysiological implication of the increase of oxidized LDL in hypothyroidism involves the decreased LDL complex entry of $\mathrm{T}_{4}$ into the cells. Human LDL contains three specific binding sites for $\mathrm{T}_{4}$ localised on apolipoprotein B-100. $\mathrm{LDL}-\mathrm{T}_{4}$ complex internalized by cell surface receptors which are decreased in number in hypothyroidism ${ }^{6}$.Furthermore, it has been suggested that oxidised LDL may activate T- lymphocytes in atherosclerotic lesions and stimulate proliferation of smooth muscle cells by induction of the expression of the gene coding for the A-chain of platelet derived growth factor. Taken altogether, these data strongly support the hypothesis that oxidised LDL is atherogenic ${ }^{7}$

\section{Conclusion}

In our study it was observed that women are at more risk of developing hypothyroidism in comparison to men. Hence thyroid function test should be included as a routine investigation for women. Central obesity in hypothyroidism is well established in this study with elevated waist circumference, waist hip ratio and BMI levels. Awareness of weight reduction and regular physical exercise are to be advised to patients 
with hypothyroidism. Hypercholesterolemia is a constant feature of hypothyroidism along with elevated LDL-C and decreased level of HDL-C. So all hypothyroid cases should be investigated for their lipid profile for early detection of cardiovascular and other degenerative diseases.

\section{References}

[1]. N. Kochupillai, clinical endocrinology in India, current science, vol. 79, No. 8,25 October 2000.

[2]. Hypothyroidism and obesity Abhyday Verna M.D., Muthukrishnan Jayarama, M.D., Hari KVS Kumar M.D., Kirtikumar D. Modi, M.D., DM., Saudi Med J 2008; vol 29(8) : 1133 -1138.

[3]. Williams textbook of endocrinology $10^{\text {th }}$ edition Saunders, Imprint of Elsevier 2003: 231-446.

[4]. Soma Gupta, Ashis Muthopadyay, Sarmila Mallik. Study of associated psychiatric diseases and cholesterol concentration in subclinical diseases and cholesterol concentration in subclinical hypothyroidism. Ind J Med Biochem 2005; 9:49-52.

[5]. Mable Deurenberg - Yap, phD, Mathew Niti, phD, Ling Li Foo et al. Diagnostic Accuracy of Anthropometric Indices for Obesity Screening Among Asian Adolescents : January 2009, Vol. 38.

[6]. Theo Diekman, Piene N.M., Democker, John J.P. Kastelein et al, increased oxidizabilty of low density lipoprotein in hypothyroidism J. Clin. Endo - metab : 1998 83: 1752-1755.

[7]. Salman razvi, lornaingoe, Gill keeka, Crispin Oates, Carolyn Mc Millan and jolanta U. Weaver The beneficial effect of L Thyroxine on cardiovascular risk factors, endothelial function and quality of life in subclinical hypothyroidism randomized crossover trail. The journal of clinical endocrinology \& metabolism 2007 vol. 92, No. 51715 -1723. 